\title{
A Perspective of the COVID-19 Pandemic in the Plastic Waste Management and Cooperatives of Waste Pickers in Brazil
}

\author{
Lais R. Lima ${ }^{1}$ (D) - Rafaela F. Gutierrez ${ }^{2} \cdot$ Sandra A. Cruz ${ }^{1}$ \\ Received: 6 July 2021 / Accepted: 25 October 2021 /Published online: 10 January 2022 \\ (c) The Author(s), under exclusive licence to Springer Nature Switzerland AG 2021
}

\begin{abstract}
Brazil is the fourth largest producer of plastic waste in the world. Among all the challenges the country had faced in the development of public policies for the banning of single-use plastics, the new coronavirus pandemic scenario determined the suspension of these laws indefinitely. In 2020, Brazil became the global epicenter of COVID-19. This scenario changed the habit and behavior of Brazilian consumers, who increased the consumption of plastics due to their importance in applications as protective material. The country also has social problems related to waste management that depend mainly on waste pickers. These workers need social visibility and protection not only to face the current health crisis but also to guarantee their income and survival. This work aims to discuss the increase in single-use plastics that are not intended for recycling and the respective environmental, economic, and social impacts for the country. We demonstrate the lack of data on waste management in Brazil and highlight the importance of the social inclusion of waste pickers for a circular economy. Especially after the change of scenario with the COVID-19 pandemic, the country must have adequate planning and improvements in waste management, recycling programs, and political intervention to raising awareness among the population and guaranteeing social rights for waste pickers.
\end{abstract}

Keywords Brazil, Waste management, Plastic, Waste pickers, COVID-19 pandemic

\section{Introduction}

Recycling emerged as a system to reduce the amount of waste generated by society and as a measure to contain the impacts of excessive consumption [1]. This system has several benefits such as reduction of pollution and use of natural resources, generation of jobs, recovery, revaluation, transformation, and environmental awareness [2]. In Brazil, recycling gained more attention with the approval of the National Policy on Solid Waste (NPSW), Law 12.305, enacted in 2010 [3]. The law comprises information on a wide

Lais R. Lima

laisroncalho@gmail.com

1 Federal University of São Carlos - UFSCar, Washington Luiz, km. 235, 13565-905 São Carlos, SP, Brazil

2 University of Toronto, Toronto, Canada 
variety of interrelated topics, such as reverse logistics, selective collection, composting, and energy recovery, among others [4]. Extended producer responsibility was also instituted as an instrument for economic and social development to facilitate the collection and return of solid waste to the business sector [3].

In Brazil, the performance of cooperatives of waste pickers occurs significantly for the contribution of steps that favor the reverse logistics proposed by NPSW 2010 in terms of door-to-door collection, transport, sorting, and pre-processing [5]. These associations establish partnerships with municipal selective collection programs, but they also operate independently from the public authorities [6]. In addition, waste pickers are usually not paid for collection and sorting services and their income is obtained from the commercialization of collected and recyclable materials such as paper, cardboard, plastic and glass, as well as ferrous and non-ferrous materials [7].

According to data from the Panorama of Solid Waste in Brazil 2020, carried out by Brazilian Association of Special Waste and Public Cleaning Companies-ABRELPE [8], Brazilians produce 1.52 million tons of waste per week. As stated by National Association of Waste pickers [9], among the materials collected in the Brazilian selective collection system in the period from 2010 to 2018, paper/cardboard was the main one (42\% of the total), followed by plastics $(23 \%)$, metals (13\%), glass (12\%), and others $(10 \%)$.

Brazil is the fourth largest producer of plastic waste in the world, behind only the USA, China, and India [10]. Despite this, plastic recycling rates in Brazil are still extremely low (1.2\%) when compared to countries as Germany (37.94\%), USA (34.60\%), UK (31.45\%), China (21.92\%), and Canada (21.25\%) [11].

During the COVID-19 pandemic, plastic consumption increased due to the production of personal protective equipment (PPE). Despite its importance for the safety of health professionals and citizens, the increase in the amount of plastic waste generated has aggravating consequences for the environment. With the lack of awareness from a large part of the population and the inadequate final destination of post-consumer plastic, the increase in the volume of this waste is quite problematic in a country where there is such a low recycling rate [12].

The low recycling rate in Brazil is due to several factors, including the unawareness of the population of recycling programs [13], a lack of tax incentives [14], non-adequate facilities and collecting vehicles [15], and the absence of adequate waste legislation [16]. In addition, recycled materials are double taxed, initially as raw materials and then as recycled [17]. As a result, the recycling market in the country is still extremely informal [18]. There is a lack of data on this market from countless autonomous waste pickers, who live in precarious conditions and are often excluded from our society. They are poor people, excluded from society because of their age, social status, low education level, or inability to enter the formal labor market [19]. This marginalized group is generally unrecognized or under-compensated and is often conducted informally and individually, resulting in low wages and weak social protection [20].

The National Movement of Waste Pickers estimates 800,000 waste pickers in the country who collect recyclable waste in the streets and sell them back to the industries. According to IPEA, waste pickers are strengthened when they are united through cooperatives. Such collective organizations help them enter the formal MSW management system [21], generating greater income for this category, better working conditions, social inclusion, and citizenship, in addition to some better operational situations, organizational conditions [19], and selling power when dealing with scrap buyers [18]. 


\section{Waste Management Challenges}

Most municipalities in Brazil do not have the recycling programs. The 2018 data from the Business Commission on Recycling (CEMPRE), shows that 1227 municipalities performed selective collection, which represents only $22 \%$ of Brazilian cities [7].

Although they work individually or as members of formalized associations and cooperatives, the waste pickers play an important role in this segment. In Brazil, they have been responsible for about $90 \%$ of the recycling collection [22]. The per capita collection of recyclable materials within the country is $14.4 \mathrm{~kg} / \mathrm{inhab} / \mathrm{year}$, which is equivalent to 1.7 million tons/year [23]. However, these quantities comprise a significant fraction of tailings, and the materials effectively recovered account for approximately 1.05 million tons/year [24].

According to the ABRELPE, Brazil produced 79 million tons of MSW in 2018, of which $3.9 \%$ were recycled and destined for composting. Of the remainder, $59.5 \%$ were properly disposed of in landfills, and despite the NSWP target of closing all dumps by 2014, 3001 municipalities improperly disposed of $40.5 \%$ in controlled dumps or landfills [25].

There is no doubt about how much, in environmental and social terms, Brazil loses from the lack of recycling. According to the Brazilian Association of Energy Waste Recovery (ABREN) - a member of the International Solid Waste Association (ISWA) - Brazil loses around 2.8 billion dollars annually in the treatment of diseases of people who have had improper contact with MSW [26]. Based on data from the World Bank, available in the 2015 Fiscal Aspects of Health in Brazil report, public spending on health in Brazil corresponded to $3.8 \%$ of the Gross Domestic Product (GDP) [27].

Data from CEMPRE (2018) also reveal that among the composition of waste from the selective collection in 2018, $13 \%$ were plastic waste [7]. In general, one of the country's strategies to mitigate the impact of plastics on the environment was to enact some laws that prohibit the use of single-use plastic. There is still no federal law that applies to the entire country. However, state laws have already been enacted in all Brazilian states banning plastic straws. Some municipal laws advance the ban on other disposable materials such as bags, glasses, cutlery, and other plastic materials [28]. The legislation supports the replacement of singleuse plastics for biodegradable or reusable ones [29]. These laws have been enacted with focus and justification to favor a circular economy in the country. However, there is still a lack of sufficient and significant data to propose actions related to this concept, as well as activities regarding environmental education, such as awareness of the local population, impacts of the incorrect disposal of plastics, and ways of reducing consumption. There are no public policies and guidance for households to properly sort their waste. Furthermore, incorrect disposal of biodegradable plastics can aggravate another environmental problem, such as the increase in the volume of landfills and dumps [30]. The appropriate conditions for biodegradation are specifically provided in industrial composting facilities, which is an incipient process in the country [31]. Only $1.9 \%$ of Brazilian municipalities have composting plants, and only 127,000 tons of MSW (0.16\% of the total) went to composting centers in 2018 [18, 32].

\section{Single-Use Plastics in Face of the COVID-19 Pandemic}

While Brazil had been enacting important laws to ban single-use plastics, the 2020 scenario created new habits that reinvigorated the plastic industry worldwide [33]. The advent of the pandemic caused by the new coronavirus (COVID-19), announced by the World Health Organization (WHO) in March 2020, has been causing major global impacts. Whereas the 
number of known infections in Europe decreased, in May 2020 Latin America became an epicenter of the pandemic, driven mainly by the increasing number of cases in Brazil. On 7 October 2021, Brazil had at least 21.4 million cases - more than the whole Europe-and more than 598,000 deaths [34].

The closure of factories and local businesses at the beginning of the pandemic resulted in a reduction in pollutant emissions into the atmosphere. A recent study shows that solid waste production, in general, of the main cities in Brazil, has decreased during the social isolation period, possibly due to reduced activity in commercial areas [35]. On the contrary, single-use plastics were more than ever essential in the daily lives of individuals, increasing the complexities of plastic waste management [36]. According to data from ABRELPE, in June 2020, there was a significant increase in the amount of solid household waste generated in Brazil $(\sim 30 \%)$ and a considerable growth in the generation of hospital waste in healthcare units (10-20 times) due to confinement [8].

Amid the risk of transmission of the virus, the population changed its patterns of behavior and consumption [37]. The excessive demand for gloves and individual protection masks, as well as plastic packaging for food, hand sanitizer and medicine, causes concern and uncertainty about the environmental advances that we have been seeking and achieving in recent years [38].

Safety concerns related to supermarket purchases during COVID-19 have led to a preference by consumers and suppliers for fresh food packaged in plastic containers (to avoid contamination of food and to extend the shelf life) and the use of single-use food packaging, as well as plastic bags to carry groceries [39].

Despite the lack of any conclusive evidence for reduced risk of viral transmission from disposable bags, the stance adopted by countries integrates the belief in society that plastic is hygienic. However, the ability of the coronavirus to survive on plastic surfaces can be up to 3 days compared to paper ( $3 \mathrm{~h}$ ), cardboard (1 day), and fabric (2 days), which contradicts this view [40-42]. Furthermore, it is not clear how reusable grocery bags can contribute to greater risk compared to clothing or shoes, a potential risk that can also be mitigated with proper hand hygiene and personal decontamination [43].

The current scenario in Brazil face changes in its public policies, as in the laws that seek to minimize environmental impacts on plastic pollution and consequently enable the use of biodegradable or reusable materials. Some laws that prohibit the distribution of disposable plastic materials are suspended indefinitely, as is the specific case of Law No. 17,261 of January 2020 in the municipality of São Paulo and that would come into effect in January 2021 [44]. Action against the law was proposed by the Syndicate of the Plastic Material Industry of the State of São Paulo (SINDIPLAST), with the justification that the ban at this time can cause problems for the health system, given the situation of a pandemic caused by a highly transmissible virus.

While plastic is an essential material for protection against virus transmission, especially cross-contamination in the current pandemic scenario, the reversal of such policies that restrict the use of disposables causes an increase in waste generation. This can again induce an unsustainable culture in consumers and contribute to the global problem of pollution caused by plastics [33, 45, 46]. 


\section{Social Impact of the Pandemic for Brazilian Waste Pickers}

The increase in COVID-19 cases has also raised concerns around the world regarding the contamination risks associated with solid waste management, particularly with a focus on medical and household waste [24, 47].

In Brazil the pandemic scenario extends the challenges of the recycling process and directly impacts the waste pickers. As the new coronavirus survives up to 3 days on plastic [41], masks, gloves, and some hospital plastics items are not being recycled due to the risk of cross-contamination of these workers. This situation becomes even more problematic due to the absence of a policy to guide waste pickers and the entire population in general.

According to the Coordination of the National Movement of Waste Pickers, in Brazil, about $15 \%$ of the cooperative members are in risk groups, over 60 years old, breastfeeding or with chronic diseases [48]. The selective collection activities are carried out manually by waste pickers and due to the scarcity of an adequate structure in the waste sorting units and the lack of access to PPE for them, the activities were suspended or reduced by the cooperatives' own decision or as determined by local authorities. Other waste pickers' organizations continued their selective collection and sorting activities or resumed them after a short period of stoppage, some without meeting the individual and work safety conditions necessary to protect against the contamination risks of COVID-19 [49].

According to a survey conducted by CEMPRE in 2020, the Northeast region of Brazil was the one that proportionally had the greatest impact on selective collection. Among $100 \%$ of the contacted municipalities that have consolidated services, only $1.5 \%$ of the selective collection was maintained in the region. The South region maintained the highest rate of service operating normally (58.9\%) and in full activity, followed by the Southeast region, with $42.5 \%$ of the operation, and the North and Center-West regions, both with $14.3 \%$ of the selective collection system operating normally during social isolation [50].

Considering the social and economic vulnerability of waste pickers, a factor to be considered inseparably from this context, as it directly influences the decision on whether or not to interrupt activities, is the need for social protection and security available to minimum income or other financial support to ensure the survival of these service providers during the pandemic period [49].

Brazil still does not present specific data on the real impact that the Pandemic has been causing in the associations and cooperatives of waste pickers. We also do not have formalized documents on any financial support for all waste pickers from federal or state agencies. According to ABIPLAST [51], 62\% of the plastic transformer industry reported problems in obtaining raw material and inputs to satisfy demand. This has resulted in an increase in the value of recycled material, which benefits the cooperatives. Nonetheless, for each state and specifically for each municipality, local management assists in different ways. According to the National Movement of Waste Pickers [52], some cooperatives have not received any assistance from government or private companies and therefore remain closed since the beginning of the health crisis. Specifically, in the city of São Paulo, the sorting of selective collection materials was interrupted in all cooperatives associated with the City Hall. Despite the interruption, the municipality has been financially supporting the workers from these cooperatives and from the Mechanized Sorting Plants of the capital of São Paulo, which maintained the operation with reduced staff [50].

In May 2020, the National Council of the Brazilian Public Ministry issued a document specifying technical and legal guidelines for the selective collection and sorting of recyclable materials during the COVID-19 pandemic. The document stimulates strategic and 
concrete actions aimed at the immediate implementation of public policies to improve the effectiveness of shared responsibility in solid waste management [49].

The document also reinforces that these measures must be promoted with greater urgency for the vulnerability of waste pickers. Consequently, it is necessary to promote the social integration of disadvantaged sectors, such as cooperatives or associations formed by low-income individuals, who have problems inherent to social and economic vulnerability and who remain exposed to various occupational risks, including biological, physical, and chemical [49]. Some of these preventive measures highlight the immediate need to expand the access of recyclable material collectors to appropriate PPE, cleaning and personal hygiene materials and other healthcare and social assistance.

Despite the benefits included in this document, the country's recycling sector lacks these supports since before the pandemic. It is urgent to guarantee the safety of waste pickers during the pandemic, but the difficulty in inserting this vulnerable group into formal recycling streams is already a challenge for years. It is essential to understand the role, circumstances, and interdependence of waste pickers for a circular economy [53]. One of the major challenges in MSW in developing countries is how best to work with this informal sector to improve their livelihoods, working conditions, and recycling efficiency [54]. Furthermore, as the community resumes their activities, there is an increase in the use of PPE and disposable plastics, which will continue to increase the generation of waste. Managing the increase in disposable plastic waste will be a huge challenge for governments, especially in developing nations, such as Brazil.

Based on official data, Brazil has a projection for the generation of MSW for the next decades, resulting in points to a growing curve over 30 years. By 2050, Brazil may have an increase of almost 50\% in the amount of MSW, compared to 2019 [55]. For the same period, the expected population growth projection is $12 \%$ (the current Brazilian population exceeds 213 million inhabitants [56]). These data evidence the decisive influence on the components of economic perspective: (1) the gradual advance of GDP; (2) consequent increase in society's purchasing power; (3) the still absent charge from citizens for solid waste collection and management services; and (4) the growing consumption of single-use disposable products [55].

Adequate planning and political intervention will be necessary to prevent aggravation and poor waste management, since the increase in single-use plastics for protection during the COVID-19 pandemic scenario may result in their outflow to the environment and triggering a new public health crisis.

\section{Final Considerations and Conclusion}

Considering Brazil's background and the current health crisis caused by the new coronavirus, it should be noted that the country is experiencing an increase in the consumption of plastic materials, especially with all the essential protection elements that include PPE and disposable packaging.

In the post-pandemic context of Brazil, to improve plastic waste management, it is necessary to induce personal behavioral and institutional social changes. Regulations related to the circular economy are important to combat the inevitable increase in the use of disposable plastics while also accelerating this economic recovery by opening a window of opportunity for a novel resource-saving eco-social preparedness system [57]. 
It is essential to unite the main actors involved in waste management, which are the legislative and governmental bodies, the cooperatives of waste pickers and private companies, in addition to the population, to follow the circular economy initiative, Fig. 1.

The most accurate solution in the face of the social-environmental impact in Brazil is based on the need for improvements in proper waste management, as well as the recycling of these materials, according to the guidelines imposed by competent authorities. These include government policies focusing on incentive measures that encourage a circular economy and sustainable practices and public-private investments in infrastructure and regularization for people and companies to take responsibility for reusing and recycling the generated waste. All these actions will help guide the country toward shared responsibility and corporate actions will help guide the country towards a more conscious path and to prevent from transitioning from one disaster to another.

The main evidence of this perspective is the need (1) for improvements in solid waste management in the whole country; (2) for improvements in the efficiency of recycling plastic waste; (3) to implement policies that address behavioral barriers of consumers, including awareness and importance of the correct disposal, reuse and recycling of plastic

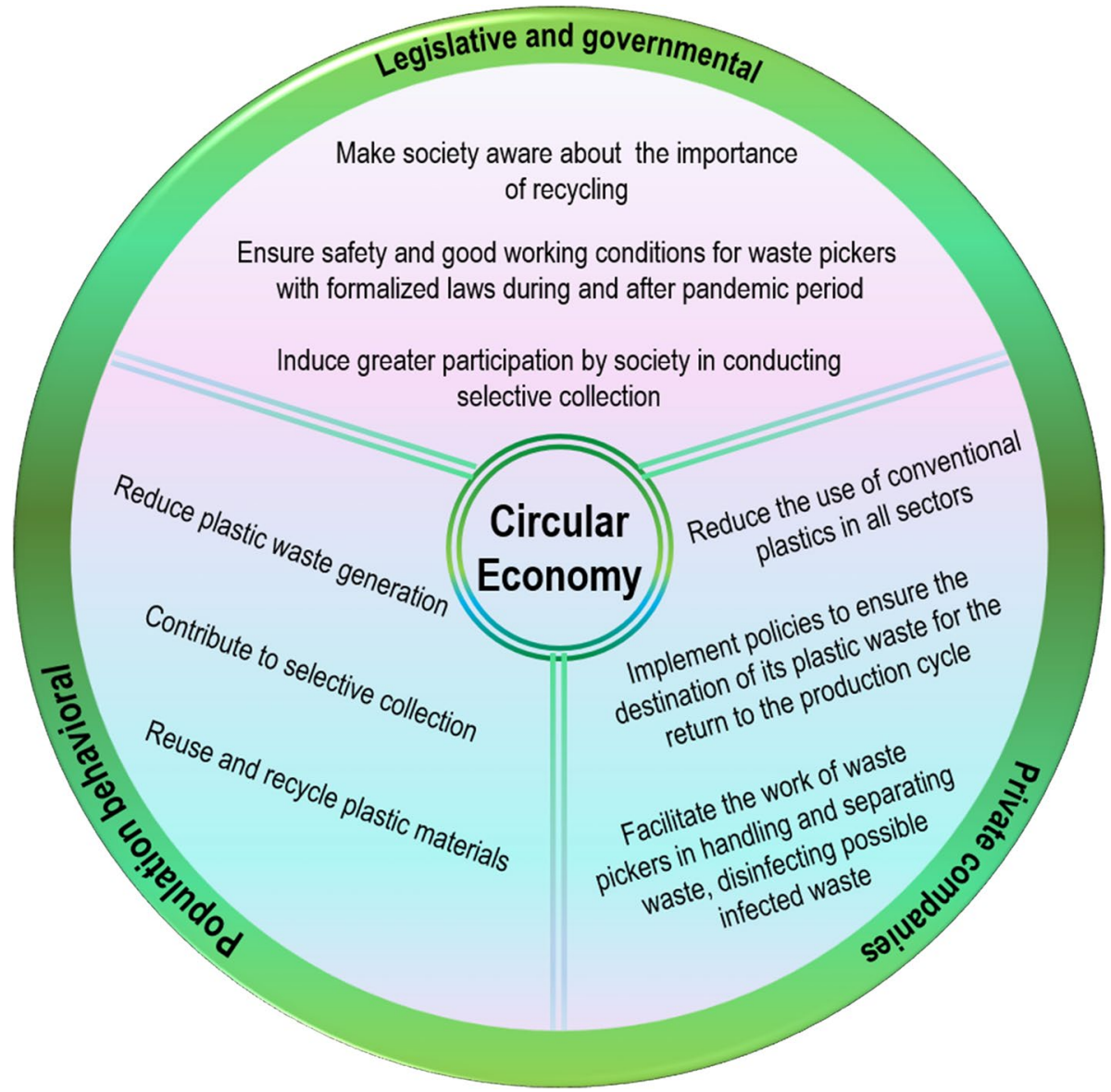

Fig. 1 Scheme that can contribute to the circular economy in Brazil 
materials; and (4) to formalize policies that guarantee protection and minimum income for waste pickers during and after the COVID-19 pandemic scenario.

Authors' Contributions Lima LR wrote the text and all authors contributed significantly to this work by reading and editing.

Funding This paper was supported by São Paulo Research Foundation (FAPESP, Brazil) through process [grant numbers \#2020/04239-1 and \#2019/02576-3].

Availability of Data and Material Not applicable.

Code Availability Not applicable.

\section{Declarations}

Conflict of Interest The authors declare no competing interests.

Ethics Approval This article does not include data human participants or biological material.

Consent to Participate Not applicable.

Consent for Publication Not applicable.

\section{References}

1. Meys R, Frick F, Westhues S et al (2020) Towards a circular economy for plastic packaging wastes the environmental potential of chemical recycling. Resour Conserv Recycl 162:105010

2. Zaman AU (2017) A strategic framework for working toward zero waste societies based on perceptions surveys. Recycling 2:1-15

3. Campos HKT (2014) Recycling in Brazil: Challenges and prospects. Resour Conserv Recycl $85: 130-138$

4. BRAZIL (2010) Law No. 12,305: National Solid Waste Policy. Federal Official Gazette of Brazil, No. 147, Section 1, p. 3,August 03th 2010. Brasília-DF, Brazil. Retrieved from https://www.planalto.gov. br/ccivil_03/_ato2007-2010/2010/lei/112305.htm. Accessed 10 Dec 2021

5. Silva de Souza Lima N, Mancini SD (2017) Integration of informal recycling sector in Brazil and the case of Sorocaba City. Waste Manag Res 35:721-729

6. Magni AAC, Günther WMR (2014) Cooperativas de catadores de materiais recicláveis como alternativa à exclusão social e sua relação com a população de rua. Saude e Soc 23:99-109

7. Business Commitment to Recycling - CEMPRE (2019) Cempre Review: Selective collection profile, p. 24-25. Retrieved from https://cempre.org.br/wp-content/uploads/2020/11/CEMPRE-Review2019. pdf. Accessed 10 Dec 2021

8. Brazilian Association of Special Waste and Public Cleaning Companies - ABRELPE (2020) Recommendations for solid waste management during the coronavirus pandemic. Retrieved from https://abrel pe.org.br/download/3347. Accessed 10 Dec 2021

9. National Association of Waste pickers (2020) Recycling Yearbook 2020 in Brazil, p. 13. Retrieved from http://anuariodareciclagem.eco.br/assets/Anua\%CC\%81rio\%20da\%20Reciclagem\%202020.pdf. Accessed 10 Dec 2021

10. de Aguiar LK, Manning L (2020) In: Aktas E, Bourlakis M (eds) The Role of Informal and Semi-Formal Waste Recycling Activities in a Reverse Logistics Model of Alternative Food Networks BT - Food Supply Chains in Cities: Modern Tools for Circularity and Sustainability. In: Springer International Publishing, Cham, pp 145-169

11. Kaza S, Yao LC, Bhada-Tata P, Van Woerden F (2018) What a Waste 2.0 : A Global Snapshot of Solid Waste Management to 2050. https://doi.org/10.1596/978-1-4648-1329-0. Retrieved from https://openk nowledge. worldbank.org/bitstream/handle/10986/30317/9781464813290.pdf? sequence=13\&isAll owed=y. Accessed 10 Dec 2021 
12. de Sousa FDB (2021) Plastic and its consequences during the COVID-19 pandemic. Environ Sci Pollut Res 28:46067-46078

13. Alves R, Ferreira KLA, Lima R, da Moraes S FTF (2021) An Action Research Study for Elaborating and Implementing an Electronic Waste Collection Program in Brazil. Syst Pract Action Res 34:91-108

14. Conke LS (2018) Barriers to waste recycling development: Evidence from Brazil. Resour Conserv Recycl 134:129-135

15. Bassin ID, Santana FL, Alves IRFS BJP, Bassin JP (2021) Chapter: Public Policies and Initiatives for Waste Minimization and Recycling in Brazil. In: Waste Management Policies and Practices in BRICS Nations by Singh P, Milshina Y, Tian K, Borthakur A, Verma P, Kumar A, 1st edition. https://doi.org/ 10.1201/9781003007579

16. Ottoni M, Dias P, Xavier LH (2020) A circular approach to the e-waste valorization through urban mining in Rio de Janeiro, Brazil. J Clean Prod 261:120990

17. Demajorovic J, Augusto EEF, De Souza MTS (2016) Reverse logistics of E-waste in developing countries: Challenges and prospects for the Brazilian model. Ambient e Soc 19:117-136

18. Mancini SD, de Medeiros GA, Paes MX et al (2021) Circular Economy and Solid Waste Management: Challenges and Opportunities in Brazil. Circ Econ Sustain 1:261-282

19. Miranda IT, Fidelis R, de Souza Fidelis DA et al (2020) The Integration of Recycling Cooperatives in the Formal Management of Municipal Solid Waste as a Strategy for the Circular Economy-The Case of Londrina, Brazil. Sustain 12:10513

20. Oliveira IA (2021) Environmental Justice and Circular Economy: Analyzing Justice for Waste Pickers in Upcoming Circular Economy in Fortaleza, Brazil. Circ Econ Sustain 1:815-834. https://doi.org/10. 1007/s43615-021-00045-w

21. Institute for Applied Economic Research - IPEA (2013) Social Situation of Recyclable and Reusable Material Waste Pickers. Retrieved from https://www.ipea.gov.br/portal/images/stories/PDFs/situacao_ social/131219_relatorio_situacaosocial_mat_reciclavel_brasil.pdf. Accessed 10 Dec 2021

22. Lima PDM, Colvero DA, Gomes AP et al (2018) Environmental assessment of existing and alternative options for management of municipal solid waste in Brazil. Waste Manag 78:857-870

23. BRAZIL (2019) Ministry of Regional Development. National Secretariat of Sanitation - SNS. National Sanitation Information System: Diagnosis of Municipal Solid Waste Management - 2018. In: Brasília SNS/MDR, 2019. 247 p. Retrieved from http://www.snis.gov.br/downloads/diagnosticos/rs/2018/ Diagnostico_RS2018.pdf. Accessed 10 Dec 2021

24. Penteado CSG, de Castro MAS (2021) Covid-19 effects on municipal solid waste management: What can effectively be done in the Brazilian scenario? Resour Conserv Recycl 164:105152

25. Brazilian Association of Special Waste and Public Cleaning Companies - ABRELPE (2019) Panorama of Solid Waste in Brazil 2018-2019. Retrieved from https://abrelpe.org.br/download/3274. Accessed 10 Dec 2021

26. Brazilian Association for Energy Recovery of Waste - ABREN (2020) Institutional plan, March 2020. Brasília-DF, Brazil, 55:1-57. Retrieved from https://abren.org.br/wp-content/uploads/2020/06/Insti tutional-Plan-ABREN-2020-mar2020.pdf. Accessed 10 Dec 2021

27. Gragnolati M, Lindelow M, Couttolenc B (2013) Twenty Years of Health System Reform in Brazil. In: Directions in Development - Human Development. An Assessment of the Sistema Único de Saúde (SUS). The World Bank. Retrieved from https://documents1.worldbank.org/curated/en/9097014680 20377135/pdf/Twenty-years-of-health-system-reform-in-Brazil-anassessment-of-the-sistema-unicode-saude.pdf. Accessed 10 Dec 2021

28. Schnurr REJ, Alboiu V, Chaudhary M et al (2018) Reducing marine pollution from single-use plastics (SUPs): A review. Mar Pollut Bull 137:157-171

29. Viera JSC, Marques MRC, Nazareth MC et al (2020) On replacing single-use plastic with so-called biodegradable ones: The case with straws. Environ Sci Policy 106:177-181

30. Allison AL, Lorencatto F, Michie S, Miodownik M (2021) Barriers and Enablers to Buying Biodegradable and Compostable Plastic Packaging. Sustain 13:1463

31. de Oliveira BOS, de Medeiros GA, Paes MX, Mancini SD (2021) Integrated Municipal and Solid Waste Management in the amazon: addressing barriers and challenges in using the Delphi Method. Int J Environ Impacts Manag Mitig Recover 4:49-61

32. Ministry of the Environment - MMA, Department of Environmental Quality (2020) Preliminary version of the National Solid Waste Plan - PLANARES. Brasília: MMA, Federal Government of Brazil, 2020. Retrieved from https://consultaspublicas.mma.gov.br/planares/wp-content/uploads/2020/07/ Plano-Nacional-de-Res\%C3\%ADduos-S\%C3\%B3lidos-Consulta-P\%C3\%BAblica.pdf. Accessed 10 Dec 2021

33. Prata JC, Silva ALP, Walker TR et al (2020) COVID-19 Pandemic Repercussions on the Use and Management of Plastics. Environ Sci Technol 54:7760-7765 
34. World Health Organization - WHO (2021) Global cases of Covid-19: Brazil (daily update). Retrieved from https://covid19.who.int/region/amro/country/br. Accessed 7 Oct 2021

35. Urban RC, Nakada LYK (2021) COVID-19 pandemic: Solid waste and environmental impacts in Brazil. Sci Total Environ 755:142471

36. Palombini FL, Cidade MK (2021) In: Muthu SS (ed) Possibilities for the Recovery and Valorization of Single-Use EPS Packaging Waste Following Its Increasing Generation During the COVID-19 Pandemic: A Case Study in Brazil BT - Sustainable Packaging. In: Springer Singapore, Singapore, pp 265-288

37. Kalina M, Ali F, Tilley E (2021) "Everything continued as normal": What happened to Africa's wave of Covid-19 waste? Waste Manag 120:277-279

38. Tenenbaum L (2020) The amount of plastic waste is surging because of the coronavirus pandemic. In: Forbes, Apr 25th 2020. Retrieved from https://www.forbes.com/sites/lauratenenbaum/2020/04/25/plast ic-waste-during-the-time-of-covid-19/\#7c4e661f7e48. Accessed 10 Dec 2021

39. de Sousa FD (2020) Pros and Cons of Plastic during the COVID-19 Pandemic. Recycl 5:27

40. van Doremalen N, Bushmaker T, Morris DH et al (2020) Aerosol and Surface Stability of SARSCoV-2 as Compared with SARS-CoV-1. N Engl J Med 382:1564-1567

41. Malik YS, Kumar N, Sircar S et al (2020) Coronavirus disease pandemic (Covid-19): Challenges and a global perspective. Pathogens 9:1-31

42. Vanapalli KR, Sharma HB, Ranjan VP et al (2021) Challenges and strategies for effective plastic waste management during and post COVID-19 pandemic. Sci Total Environ 750:141514

43. Patrício Silva AL, Prata JC, Walker TR et al (2021) Increased plastic pollution due to COVID-19 pandemic: Challenges and recommendations. Chem Eng J 405:126683

44. São P (2020) Law No. 17,261: Provides for the prohibition of supplying plastic products for single use in the places specified. Official Gazette of the municipality of São Paulo. São Paulo-SP, Brazil, No. 8, Section 1, pp. 1, Jan 4th 2020. Retrieved from http://diariooficial.imprensaoficial.com.br/nav_v5/ index.asp? $\mathrm{c}=1 \& \mathrm{e}=20200114 \& \mathrm{p}=1$. Accessed $10 \mathrm{Dec} 2021$

45. Klemeš JJ, Fan Y, Van, Tan RR, Jiang P (2020) Minimising the present and future plastic waste, energy and environmental footprints related to COVID-19. Renew Sustain Energy Rev 127:109883

46. Patrício Silva AL, Prata JC, Walker TR et al (2020) Rethinking and optimising plastic waste management under COVID-19 pandemic: Policy solutions based on redesign and reduction of single-use plastics and personal protective equipment. Sci Total Environ 742:140565

47. Antoniadou M, Varzakas T, Tzoutzas I (2021) Circular Economy in Conjunction with Treatment Methodologies in the Biomedical and Dental Waste Sectors. Circ Econ Sustain 1:563-592

48. Women in Informal Employment: Globalizing and Organizing - WIEGO (2020) Impacts of the COVID-19 Pandemic on Inclusive Recycling in Brazil. By Dias S, Abussafy R, Gonçalves J, Martins JP. June 2020. Retrieved from https://www.wiego.org/sites/default/files/publications/file/Impacts\% 20of\%20the\%20COVID-19\%20Pandemic\%20on\%20Inclusive\%20Recycling\%20in\%20Brazil\%20for\% 20web\%20\%281\%29.pdf. Accessed 10 Dec 2021

49. National Council of the Brazilian Public Ministry (2020) Technical and legal guidelines for selective collection and screening of recyclable materials during the COVID-19 pandemic. Retrieved from https://www.cnmp.mp.br/portal/images/noticias/2020/maio/26-05_DIRETRIZES_COLETA_SELET IVA_E_COVID_FINAL_1.pdf. Accessed 10 Dec 2021

50. Business Commitment to Recycling - CEMPRE (2020) CicloSoft Research - Executive Summary. Retrieved from https://ciclosoft.cempre.org.br/api/download/42de6520-59d5-11ec-b871-d309e87891 c9. Accessed 10 Dec 2021

51. Goulart J, Costa M (2021) Economic Radar: There is a lack of plastic, such as PVC, for the manufacture of hospital products. Retrieved from https://veja.abril.com.br/blog/radar-economico/falta-plasticocomo-pvc-para-fabricacao-de-produtoshospitalares/. Accessed 10 Dec 2021

52. National Movement of Waste Pickers - MNCR (2021) Covid-19: Defenders and MPT recommend protection for waste pickers. https://www.mncr.org.br/noticias/noticias-regionais/covid-19-defensorias-empt-recomendam-protecao-a-catadoras-ecatadores. Accessed 10 Dec 2021

53. Barford A, Ahmad SR (2021) A Call for a Socially Restorative Circular Economy: Waste Pickers in the Recycled Plastics Supply Chain. Circ Econ Sustain 1:761-782

54. Wilson DC, Velis C, Cheeseman C (2006) Role of informal sector recycling in waste management in developing countries. Habitat Int 30:797-808

55. Brazilian Association of Special Waste and Public Cleaning Companies - ABRELPE (2020) Panorama of Solid Waste in Brazil 2020. Retrieved from https://abrelpe.org.br/download/5692. Accessed 10 Dec 2021 
56. Brazilian Institute of Geography and Statistics - IBGE (2021) Brazilian population updated in real time. Retrieved from https://www.ibge.gov.br/apps/populacao/projecao/box_popclock.php. Accessed 6 Oct 2021

57. Possas, C., Marques, E.T.A., Risi, J.B. et al. COVID-19 and Future Disease X in Circular Economy Transition: Redesigning Pandemic Preparedness to Prevent a Global Disaster. Circ.Econ.Sust. (2021). Retrieved from https://link.springer.com/content/pdf/10.1007/s43615-021-00060-x.pdf. Accessed 10 Dec 2021

Publisher's Note Springer Nature remains neutral with regard to jurisdictional claims in published maps and institutional affiliations. 